\title{
Kedudukan Alkitab Bagi Kurikulum Di Era Revolusi Industri 4.0 Bagi Orang Dewasa
}

\section{Ottovianus Otto}

Sekolah Tinggi Teologi Pelita Dunia ottoo0919@gmail.com.

\begin{abstract}
This paper aims to see how the Bible stands for the curriculum in the era of the industrial revolution 4.0 called the Internet of Think (IoT). Internet of Think (IoT) is a technology that allows each instrument to be connected to one another virtually, so that it can support the performance of the human workforce. Therefore, with the development of the 4.0 industrial revolution, this paper will explain how the authority of the Bible and the relevance of the Bible, the benefits of God's words based on II Timothy 3:16 (teaching, reproving mistakes, correcting behavior and educating people in truth) and the position of the Bible for curriculum in the era of the industrial revolution 4.0.
\end{abstract}

Keywords: Bible, Curriculum, Industrial Revolution 4.0

Abstrak: Tulisan ini bertujuan untuk melihat bagaimana kedudukan Alkitab bagi kurikulum di era revolusi industri 4.0 yang disebut Internet of Think (IoT). Internet of Think (IoT) merupakan teknologi yang memungkinkan setiap instrumen terkoneksi satu sama lain secara virtual, sehingga mampu mendukung kinerja tenaga kerja manusia. Oleh karena itu, dengan adanya perkembangan revolusi industri 4.0 maka, tulisan ini akan menjelaskan bagaimana otoritas Alkitab dan relevansi Alkitab, manfaat perkataan Allah berdasarkan II Timotius 3:16 (mengajar, menyatakan kesalahan, memperbaiki kelakuan dan mendidik orang dalam kebenaran) dan kedudukan Alkitab bagi kurikulum di era revolusi industri 4.0.

Kata Kunci: Alkitab, Kurikulum, Revolusi Industri 4.0

\section{Pendahuluan}

Kemajuan teknologi di era revolusi industri 4.0 telah merambat keseluruh aspek kehidupan manusia. Tidak ada satu ruangpun yang tidak dipengaruhi oleh revolusi industri 4.0. Oleh karena globalisasi tersebut, maka muncul pertanyaan yang bersifat agamawi yaitu apakah kedudukan Alkitab bagi kurikulum di era revolusi industri 4.0?. Apakah Alkitab tetap menjadi otoritas tertinggi dalam kurikulum?. Secara khusus, penulis akan membahas prinsip dan nilai dalam kurikulum di era revolusi industri 4.0 bagi orang dewasa. Orang 
dewasa yang penulis maksudkan berkisar pada umur 18-60 tahun. Hurlock dalam buku yang berjudul Psikologi Perkembangan membaginya menjadi 2 tahap yaitu masa dewasa dini yang berusia dari 18-40 dan masa dewasa madya yang berumur 40-60 tahun. ${ }^{1}$ Oleh karena itu, kategori dewasa yang dimaksud penulis berkisar mulai umur 18-60 tahun.

Agar dapat menjawab kedudukan Alkitab bagi kurikulum di era revolusi industri 4.0, maka penulis membahas tentang: Perkembangan revolusi industri 4.0, otoritas Alkitab dan relevansi Alkitab, manfaat perkataan Allah berdasarkan II Timotius 3:16 (mengajar, menyatakan kesalahan, memperbaiki kelakuan dan mendidik orang dalam kebenaran) dan kedudukan Alkitab bagi kurikulum di era 4.0.

\section{Metode Penelitian}

Pada penelitian ini, penulis atau peneliti menggunakan pendekatan atau metode kualitatif untuk memperoleh data yang valid guna membangun sebuah teori yang berkaitan dengan tema atau pokok penelitian. Metode kualitatif yang dimaksud adalah mengkaji dan mengelaborasi setiap sumber, informasi dan data-data yang diperoleh dari pustaka.

\section{Hasil dan Pembahasan}

\section{Revolusi Industri 4.0}

Kemajuan teknologi telah mengubah wajah perekonomian, khususnya di sektor industri dan perdagangan. Salah satu fase penting dalam perkembangan teknologi adalah munculnya revolusi industri gelombang ke-4, atau yang lebih dikenal dengan sebutan Industrial Revolution 4.0.2 Studi menyebutkan istilah revolusi industri 4.0 pertama kali muncul pada tahun 2012, ketika pemerintah Jerman memperkenalkan strategi pemanfaatan teknologi yang disebut dengan Industri 4.0. Industri 4.0 merupakan salah satu pelaksanaan proyek Strategi Teknologi Modern Jerman 2020 (Germany's High-Tech Strategy 2020). Strategi tersebut diimplementasikan melalui peningkatan teknologi sektor manufaktur, penciptaan kerangka kebijaksanaan strategis yang konsisten, serta penetapan prioritas tertentu dalam menghadapi kompetisi global. ${ }^{3}$

\footnotetext{
${ }^{1}$ E. B. Hurlock, Psikologi Perkembangan (Jakarta: Erlangga, 2017), 245.

${ }^{2}$ Setiyo, http://www.ajarekonomi.com/2018/05/perkembangan-revolusi-industri-4.0.

${ }^{3}$ Ibid., Perkembangan Revolusi Industri 4.0.
} 
Revolusi Industri 4.0 adalah otomatisasi sistem produksi menggunakan teknologi dan data besar. Di mana dalam proses produksi tersebut telah menggunakan teknologi baru seperti IoT (Internet of Things). Istilah ini digunakan oleh pemerintah Jerman untuk memajukan bidang industri teknologi. Mengutip halaman Forbes, revolusi industri generasi keempat dapat diartikan sebagai gangguan dalam sistem sektor yang cerdas dan otomatis. Ini didorong oleh data melalui pembelajaran mesin dan teknologi AI (kecerdasan buatan). Revolusi Industri 4.0 adalah upaya transformasional untuk meningkatkan sistem dengan mengintegrasikan dunia online dan lini produksi sektor ini, di mana semua proses produksi dijalankan melalui Internet sebagai andalan. ${ }^{4}$ Dalam salah satu studinya, The World Economic Forum (WEF) menyatakan bahwa revolusi industri 4.0 ditandai oleh pembaruan (fusion) teknologi yang mampu menghapus batas-batas penggerak aktivitas ekonomi, baik dari perspektif fisik, digital, maupun biologi. ${ }^{5}$

Karakteristik revolusi industri 4.0 ditandai dengan berbagai teknologi terapan (applied technology), seperti advances robotics, artificial intelligence, internet of things, virtual and augmented reality, additive manufacturing, serta distributed manufacturing yang secara keseluruhan mampu mengubah pola produksi dan model bisnis di berbagai sektor industri. Adapun pergertian dari istilah-istilah tersebut adalah:

1. Advances robotics. Instrumen ini merupakan peralatan yang digunakan secara mandiri, yang mampu berinteraksi secara langsung dengan manusia, serta menyesuaikan perilaku berdasarkan sensor data yang diberikan. Fungsi utamanya adalah untuk memperpendek waktu tunggu dan waktu layanan, sehingga menghasilkan efisiensi.

2. Artificial Intelligence (AI). AI adalah sistem mesin berteknologi komputer yang mampu mengadopsi kemampuan manusia. Ini dimaksudkan untuk meningkatkan kinerja dan produktivitas, sekaligus meminimalisir risiko kesalahan yang bisa dilakukan oleh tenaga kerja manusia.

\footnotetext{
${ }^{4}$ Nancy W. Gleason, Higher Education In The Era Of The Fourth Industrian Revolutin, (Singapore: Yale-NUS Collage, 2018), 207.

${ }^{5}$ Ibid., 207.
} 
3. Internet of Things (IoT). IoT merupakan teknologi yang memungkinkan setiap instrumen terkoneksi satu sama lain secara virtual, sehingga mampu mendukung kinerja tenaga kerja manusia.

4. Virtual and Augmented Reality. Virtual Reality merupakan simulasi yang dilakukan oleh komputer dalam membentuk sebuah realitas rekan. Sementara Augmented Reality adalah teknologi yang mampu menghasilkan informasi dari kondisi lingkungan sebenarnya, lalu diproses secara digital dan digunakan untuk tujuan tertentu.

5. Additive Manufacturing. Teknologi ini merupakan otomatisasi proses produksi melalui teknologi 3D (three dimensional). Hal ini memberi pengaruh positif pada kecepatan pengolahan dan transportasi produk.

6. Distributed Manufacturing. Merupakan konsep penempatan lokasi produksi dan pengintegrasian proses produksi, sehingga bisa berada sedekat mungkin dengan konsumen untuk menjawab kebutuhan rill mereka. Tujuannya adalah untuk mencapai economies of scale, sekaligus mengurangi beban biaya (cost efficiency). ${ }^{6}$

Disertai dengan perkembangan teknologi yang semakin canggih, revolusi industri 4.0 telah mulai memasuki eranya, yakni menekankan pada pola digital economy, arficial inteligence, big data, robotic, dan lain sebagainya atau dikenal dengan fenomena disruptive innovation. ${ }^{7}$

7. Disertai dengan perkembangan teknologi yang semakin canggih, revolusi industri 4.0 telah mulai memasuki eranya, yakni menekankan pada pola digital economy, arficial inteligence, big data, robotic, dan lain sebagainya atau dikenal dengan fenomena disruptive innovation. ${ }^{8}$

Pada tahun 2020, perusahaan industri Eropa akan menginvestasikan 140 miliar euro setiap tahun dalam solusi Internet industri. Selama lima tahun ke depan, perusahaan industri Eropa akan menghabiskan rata-rata 3,3\% dari pendapatan tahunan mereka untuk solusi Internet (digital) untuk industri ini. Jika secara total semua perusahaan, biaya yang dikeluarkan mencapai hampir 50\% dari investasi modal baru yang direncanakan. Jumlahnya dalam satu tahun bisa mencapai lebih dari 140 miliar euro. Solusi Internet ini

\footnotetext{
${ }^{6}$ Ibid., 207.

${ }^{7}$ Muhammad Imaduddin, Membuat Kelas Online Berbasis Android dengan Google Classroom Terobosan Pembelajaran Era Revolusi Industri 4.0, (Yogyakarta: Garudhawaca, 2018), 1.

${ }^{8}$ Ibid., 1.
} 
berkisar dari Internet of Things (IoT) hingga kecerdasan buatan (AI) hingga berbagai teknologi Internet. Selama lima tahun ke depan, lebih dari 80\% bisnis akan mendigitalkan seluruh proses bisnis. 25\% perusahaan yang disurvei oleh PWC mendigitalkan tonggak tingkat tinggi dalam proses mereka. Responden juga mengharapkan digitalisasi bisnis mereka mencapai 86\% secara horizontal (di semua divisi atau unit) dan $80 \%$ secara vertikal (dari bawah ke atas). Perusahaan-perusahaan Eropa akan memiliki tingkat digitalisasi yang tinggi pada tahun 2020 dan akan terintegrasi secara erat. ${ }^{9}$

Generasi yang hidup di era revolusi industri 4.0 dimana semua dapat diakses dengan cepat dan bebas oleh siapa saja. Tidak menutup kemungkinan bahwa sesuatu yang akan di akses adalah hal-hal yang positif atau negatif. Dalam hal ini para pengguna media sosial diharapkan mampu menilai secara kritis segala informasi yang terdapat di media sosial yang berbasis internet, serta mencari tahu kebenaran dari segala informasi yang didapat. Namun bagaimana sikap pemuda remaja dan orang dewasa khususnya dalam menyikapi segala kemungkinan-kemungkinan yang ada saat bersosial media, yakni mampu melihat dampak-dampak yang terjadi dalam penggunaan media sosial.

Ada pun dampak positif dan dampak negatif dalam menyikapi era revolusi industri 4.0 adalah:

\section{Dampak positif}

$>$ Memudahkan dalam memperoleh informasi. Dengan adanya internet akan mempermudah pemuda remaja dalam mengakses situs-situs pendidikan, renungan, berita, dan informasi lainnya untuk menambah wawasan.

$>$ Menjadi media komunikasi. Sosial media dapat dijadikan sebagai media komunikasi dalam lingkup dunia maya baik itu melalui WA, Mesenger, Fb, Twitter, Instagram, Youtobe.

$>$ Memperluas jaringan pertemanan. Berkat media sosial pemuda remaja lebih mudah dalam menemukan teman, walaupun sebagian besar temannya tidak di temui secara langsung.

\footnotetext{
${ }^{9}$ Ibid., 1.
} 
Tempat usaha online. Media sosial dapat dijadikan sebagai tempat usaha dalam mempromosikan barang dagangan melalui iklan, bloger, youtube dan situs lainnya.

$>$ Tempat mengemukakan kreativitas. Dalam media soaial para remaja pemuda mampu menampilkan kemampuan kreativitas mereka melaui karya tulis ilmiah maupun fiksi yang berupa cerpen, novel, puisi, desain, dan lain sebagainya, yang membuat mereka lebih menjadi diri sendiri.

$>$ Tempat belajar. Dengan situs internet memudahkan remaja pemuda untuk belajar secara online, melalui situs-situs yang di programkan secara khusus yang di dalamnya terdapat kumpulan berbagai macam mata pelajaran yang mudah di akses. ${ }^{10}$

$>$ Media berbagi sharing. Dengan kemajuan yang ada seseorang dapat menguatkan satu dengan lain melaui sharing firman Tuhan, atau kata-kata motivasi yang akan menggairahkan hidup orang lain.

\section{Dampak Negatif}

> Susah bergaul. Media sosial menjadikan remaja pemuda menjadi susah bergaul di dunia nyata, menjadi seseorang yang menutup diri terhadap lingkungan, jika dalam dunia maya seorang pemuda adalah seorang yang ramah dan bersahabat, berbeda halnya saat berada di dunianya yang nyata dia akan menjadi orang pasif dan enggan bergaul seperti sikapnya saat mengahadapi teman-temannya di media sosial.

$>$ Menjadi egois. Karena jarangnya berkomunikasi secara langsung remaja pemuda menjadi seseorang yang hanya mementingkan diri sendiri dan tidak mampu berempati terhadap sesama.

$>$ Prestasi menurun. Dalam kurun waktu yang digunakan untuk melakukan kegiatan $1 / 2$ nya adalah bermain media sosial. Misalnya membuka fb, instagram, twitter hanya sekedar melihat status orang, menulis status, dan berkomentar di kolom komentar, yang mengakibatkan tersitanya waktu dalam belajar maupun bekerja. Sehingga berdampak pada prestasi yang menjadi menurun.

${ }^{10}$ https://tscumum2011.blogspot.com/2013/ remaja.html\#8q6FWX9WUKCVVFx9.99. 
Pornografi. Dengan kemampuan penyampaian informasi yang dimiliki internet maka pornografi merajalela. Misalnya seseorang memposting foto pribadi yang seharusnya menjadi konsumsi pribadi disebarluaskan oleh oknum yang tidak bertanggungjawab dan menjadi konsumsi publik.

$>$ Terjadinya kejahatan. Kejahatan dunia maya atau lebih dikenal dengan cyber crime, seperti:

- Hacking, seseorang yang mempunyai minat besar untuk mempelajari system computer secara detail dan bagaimana meningkatkan kapabilitasnya.

- Cracking, yaitu kejahatan membajak account, pembajakan situs web, penyebaran virus dalam program computer secara sengaja.

- Spamming, yaitu kejahatan yang berupa berita yang isinya tidak dapat di pertanggungjawabkan (hoax).

- Cyber terrorism, adalah penggunaan internet untuk melakukan tindakan kekerasan yang mengakibatkan atau mengancam hilangnya nyawa atau kerugian fisik yang signifikan untuk mencapai keuntungan melalui intimidasi. ${ }^{11}$

Dengan bersosial media seseorang bisa mempunyai kehidupan "ganda" yakni kehidupan di dunia nyata dan kehidupan di dunia maya. Yang dimana seorang terlihat pasif namun aktif dalam komunitas media sosial. ${ }^{12}$ Setelah mengetahui dampak-dampak media sosial secara positif dan negatif, maka remaja pemuda diharapkan agar menjadi lebih cerdas dan berhati-hati dalam menggunakan media sosial yang berbasis internet. Tidak menjadi seorang pecandu yang sulit melepaskan diri dan menjadi ketergantungan, membuat dunia sendiri dengan mengabaikan dunia yang sehungguhnya dimana ada orangorang yang mengasihi secara nyata bukan maya. Remaja pemuda merupakan generasi penerus yang memiliki karakter yang baik, cerdas, kuat dan kritis tentunya yang akan memberikan sumbangsih melalui karya-karya yang akan dimuat dalam media sosial dan dapat diakses oleh siapapun, yang tentunya tidak terlepas dari norma, kaidah dan etika yang berlaku dalam penggunaan media sosial.

\section{Otoritas dan Relevansi IPTEK Dalam Alkitab}

\footnotetext{
${ }^{11}$ http://jaringankomputer.org/cyber-crime-adalah-jenis-tindak-kejahatan-internet/.

${ }^{12}$ Budi Hardiman Homo Digital (Jakarta: Jurnal).
} 
IPTEK adalah akronim dari Ilmu Pengetahuan dan Teknologi. Ilmu adalah pengetahuan dan yang sudah diklarifikasi, diorganisasi, disistematisasi, dan diinterpretasi, menghasilkan kebenaran obyektif, sudah diuji kebenarannya, dan dapat diuji ulang secara ilmiah. Dalam Kamus Besar Bahasa Indonesia, ilmu pengetahuan adalah pengetahuan tentang suatu bidang yang disusun secara bersistem menurut metode tertentu, yang dapat digunakan menerangkan gejala-gejala tertentu. Berikut ini dijelaskan beberapa definisi menurut para ahli sebagai berkut:

Karl Pearson mengatakan, ilmu adalah lukisan atau keterangan yang komprehensif dan konsisten tentang fakta pengalaman dengan istilah yang sederhana.

Ashley Montagu mengatakan ilmu adalah pengetahuan yang disusun dalam satu sistem yang berasal dari pengamatan, studi dan percobaan untuk menentukan hakikat prisnsip hal yang sedang dikaji. ${ }^{13}$

Era digital adalah sebuah keniscayaan. Kini manusia tak dapat lagi menolaknya atau melawannya. Ini sebuah fenomena kehidupan modern yang merupakan bagian yang tak bisa lagi dipisahkan dari kehidupan setiap orang maupun lembaga. Bahkan dalam banyak hal era digital ini mempengaruhi kehidupan manusia saat ini termasuk juga mempengaruhi anak-anak Tuhan. Kemajuan teknologi digital saat ini telah membawa manusia dalam sebuah dunia yang baru, sebuah dunia yang tidak bisa lagi dilepaskan dari perangkat elektronik dan juga tidak bisa hindari oleh manusia. Kini manusia berada dalam gelombang era digital. ${ }^{14}$

\section{IPTEK dalam Alkitab}

Sebelumnya, sangat perlu membedakan ilmu pengetahuan dari teknologi. "Ilmu pengetahuan merupakan karya budi yang logis dan imajinatif. Tanpa imajinatif dan logika dari seorang Kopernikus, suatu gagasan besar tentang heliosentrisme tidak akan muncul. Begitu juga halnya jika kita berbicara tentang ilmuan-ilmuan lain. Metode-metode ilmu pengetahuan adalah metode-metode yang logis karena ilmu pengetahuan mempraktekkan

\footnotetext{
${ }^{13}$ Moh. Rifai, PAI Interdisipliner (Yogyakarta: CV.Budi Utama, 2010), 46.

${ }^{14}$ Berita Oikumene, Dalam Gelombang Era Digital, (Jakarta: PGI. 2016).
} 
logika. ${ }^{15}$ Ilmu pengetahuan juga dapat diartikan sebagai suatu pengetahuan yang mencoba mengungkapkan misteri alam beserta isinya. Hal tersebut memungkinkan manusia dapat menyingkap misteri alam, memanfaatkan dan meramalkan sesuatu yang bakal terjadi di kemudian hari. Oleh karena itu, ilmu pengetahuan membatasi ruang geraknya pada segenap gejala yang dapat ditangkap oleh pengalaman manusia melalui panca inderanya. ${ }^{16}$ Sedangkan teknologi dalam hakekatnya meliputi pengetahuan yang sistematik disertai dengan penerapan hasil pengetahuan sebagai kegiatan dalam perkembangan masyarakat. ${ }^{17}$

Dari pengertian ini bisa dilihat bahwa ilmu pengetahuan cenderung berpijak pada teori, sedangkan teknologi merupakan suatu ilmu terapan. Namun jika diselidiki dengan seksama maka ditemukan adanya kesamaan, yaitu keduanya bersangkut-paut dengan ide manusia dan berobjek pada alam semesta.

IPTEK sudah dimulai sejak zaman Alkitab atau sejak awal sejarah manusia. Secara filosofis, setelah kejatuhan ke dalam dosa, ide dan pemikiran manusia selalu dipengaruhi oleh dua kekuatan: manusia dengan ide dan pemikiran yang telah dipulihkan oleh Allah atau ide dan pemikiran yang tetap dalam dosa." Dua pengaruh ini akan tampak terlihat pada tujuan dan karya-karya manusia dalam IPTEK.

Beberapa contoh dapat diketengahkan sebagai berikut:

Pertama, dalam sejarah air bah dengan jelas bahwa Allah memerintahkan Nuh membuat kapal untuk menyelamatkan ia dan keluarganya dari kebinasaan akibat air bah dan kebobrokan moral dunia pada waktu itu. Dimensi ruang dalam kapal ataupun bahan telah ditentukan oleh Allah (Kejadian 6:14-15). Kedua, ketika Musa diperintahkan untuk membuat Kemah Suci (Keluaran 25:9), Allah sendiri telah menjadi arsitek yang merencanakan ruang-ruang, dimensi dan bahan untuk kemah suci tersebut (Keluaran 25:127:21). Kemudian kita membaca bahwa kemuliaan Allah memenuhi Kemah Suci tersebut (Keluaran 40:35).

Ketiga, tentang Bait Suci dan istana yang dibangun oleh Salomo (1 Raja-raja 78). Dari contoh-contoh di atas dapat dilihat bahwa Allah tidak pernah menghalangi ataupun menutup segala perkembangan IPTEK. Kita pun melihat dalam contoh-contoh ini

\footnotetext{
${ }^{15}$ A. Sonny Keraf Mikhael Dua, Ilmu Pengetahuan Sebuah Tinjauan Filosofis (Yogyakarta: Anggota IKAPI, 2001), 24.

${ }^{16}$ H. Darmadi, Integrasi Agama dan IImu Pengetahuan (Yogyakarta: Anggota IKAPI, 2017), 38.

${ }^{17}$ Y.B. Mangunwijayat, Teknologi Dan Dampak Kebudayaannya (Yayasan Obor Indonesia, 1983), 2.
} 
bahwa setiap teknologi selalu di kaitkan dengan keselamatan dan maksud Allah terhadap manusia dan dunia. Akan tetapi di sisi lain, terlihat bahwa Allah juga menentang setiap penciptaan teknologi yang bermotivasikan kebesaran diri, kelompok, ataupun bangsa. Beberapa contoh kemarahan Allah saat manusia memegahkan dirinya dengan pengetahuannya tersebut adalah:

1. Ketika Allah memporak-porandakan Babel (Kejadian 11:1-9), yang ditentang bukanlah pendirian kota dan menara Babelnya tapi motivasi mereka yang mencari nama dan ingin menyamai Allah (Kej 11:4).

2. Kemewahan, gemerlap teknologi di zaman Salomo dapat menyebabkan dia banyak mengoleksi wanita asing sehingga dia kemudian jatuh kepada penyembahan berhala (1 Raja-raja 11:1-13).

3. Ketika murid-murid menunjuk kepada bangunan Bait Suci, Yesus mengatakan bahwa bangunan tersebut akan diruntuhkan (Matius 24:1-2).

4. Tuhan Yesus juga menentang penyalahgunaan fungsi Bait Suci yang dibangun selama empat puluh enam tahun menjadi arena komersil (Yohanes 2:16). ${ }^{18}$

Dari tinjauan Alkitab ini bisa disimpulkan bahwa IPTEK telah dimulai sejak awal sejarah manusia. Manusia memiliki daya cipta IPTEK karena dia diciptakan sebagai gambar Allah dan sebagai pribadi yang berakal budi. Allah sendiri adalah pencipta alam semesta, pendorong dan pencetus ide terhadap lahirnya IPTEK. Kita harus ingat bahwa Yesus sendiri adalah tukang kayu (Markus 5:3). Ia adalah seorang yang mengerti pondasi dan mekanika tanah (Matius 7:24-27). Allah tidak pernah membatasi daya cipta dan kreasi manusia akan IPTEK. Namun perlu juga dicatat bahwa ide dan tujuan penciptaan IPTEK dan produknya oleh manusia akan dipengaruhi oleh pandangan-pandangannya terhadap Allah, manusia dan alam semesta. ${ }^{19}$

\section{Manfaat Perkataan Allah Berdasarkan II Timotius 3:16}

Paulus mengajarkan kepada Timotius bahwa Firman Tuhan memiliki manfaat mengajar, menyatakan kesalahan, memperbaiki kelakuan dan mendidik orang dalam Kebenaran, karena firman Tuhan diilhamkan oleh Allah. Hal senada diungkapkan

\footnotetext{
${ }^{18}$ James Barr, Alkitab di Dunia Modern, (Jakarta: BPK Gunung Mulia: 1979), 78-80.

${ }^{19}$ Ibid., 78-80.
} 
Gregorius dari Nyssa yang dikutip oleh Peter Gorday: Alkitab "diberikan melalui ilham Allah," seperti yang dikatakan rasul. Alkitab diwahyukan oleh Roh Kudus, dimaksudkan agar bermanfaat bagi manusia. Untuk "Kitab Suci," di ilham Allah dan bermanfaat. "manfaatnya bermacam-macam dan beragam, seperti yang dikatakan rasul-rasul untuk doktrin, untuk teguran, untuk koreksi, untuk pengajaran dalam kebenaran. ${ }^{20}$

Ketika Paulus mengatakan "semua tulisan suci," adalah semua Perjanjian Lama. Kata inspirasi berarti "dihembuskan oleh Allah." Yang menakjubkan adalah bahwa Allah menggunakan kepribadian para penulis Alkitab untuk mengungkapkan hal-hal dalam pola pikir mereka sendiri, namun apa yang disampaikan sesuai dengan firman yang Ia ingin katakan. Melalui para penulis Alkitab, Tuhan telah memberikan kepada orang percaya Firman-Nya. ${ }^{21}$

Penulis akan menguraikan maksud dari istilah yang diberikan Paulus kepada Timotius maupun kepada orang di segala abad dan zaman, yaitu: Mengajar (Teaching), Menyatakan kesalahan (Reproof), Memperbaiki kelakuan (Correction), Mendidik orang dalam Kebenaran (Instruction which is in Righteousness).

\section{Mengajar (Teaching)}

Alkitab adalah sumber dari doktrin Kristen. Paulus menggunakan istilah "mengajar" (didaskalia) sebanyak lima belas kali dalam Surat-surat Pastoral dan dalam sisa Perjanjian Baru itu hanya muncul enam kali. Beberapa surat-surat Paulus biasa orang menyebutkan surat Pastoral seperti I Tim. 1:10; 4: 1, 6, 13, 16; 5:17; 6: 1, 3; II Tim. 3:10, 16; 4: 3; Tit. 1: 9; 2: 1, 7; 2:10. Dalam sisa Perjanjian Baru, terdapat pada Mat. 15: 9; Mar. 7: 7; Rm. 12: 7; 15: 4; Ef. 4:14; Kol. 2:22.) Oleh karena keunggulan ajaran sesat di antara para pembacanya, maka Paulus menekankan pentingnya pengajaran yang sehat. ${ }^{22}$ Menurut Ola Tulluan ada dua penekanan surat II Timotius yaitu:

1. Berjuang melawan ajaran sesat

${ }^{20}$ Peter Gorday, Colossians, 1-2 Thessalonians, 1-2 Timothy, Titus, Philemon (Downers Grove, Ill. : InterVarsity Press, 2000), 269.

21 J. Vernon McGee, Thru the Bible Commentary: The Epistles (1 and 2 Timothy/Titus/Philemon) (Nashville: Thomas Nelson, 1991), 124.

${ }^{22}$ Thomas D. Lea, Hayne P.Griffin, $1 \& 2$ Timothy, The New American Commentary 34 Titus (Nashville: Broadman \& Holman Publishers, 2001, c1992), 236. 
2. Jangan berkompromi kepada ajaran sesat yang ada diantara jemaat. ${ }^{23}$

John Drane berpendapat bahwa Timotius menghadapi ancaman dari para pengajar Kristen yang bercorak Yahudi, Asketik dan gnostik. Timotius menghadapi tekanan agar mereka meninggalkan ajaran seperti yang disampaikan Paulus. ${ }^{24}$

Istilah didaskalia pada bagian teks ini tidak tidak merujuk pada proses atau metode pengajaran, tetapi pada isi konten pengajaran. Dalam konteks ini, didaskalia merujuk secara khusus dan eksklusif pada instruksi ilahi atau doktrin yang diberikan kepada orangorang percaya melalui Firman Allah (Perjanjian Lama dan Perjanjian Baru). ${ }^{25}$ Menurut Philip Towner Mengajar mencakup instruksi dalam doktrin dan hal-hal tentang perilaku Kristen, dalam konteks ini penekanannya lebih pada membangun komunitas orang percaya daripada memberitakan Injil kepada orang yang tidak percaya. ${ }^{26}$

\section{Menyatakan kesalahan (Reproof)}

Manfaat kedua dari Firman dalam kehidupan orang percaya adalah menyatakan kesalahan. Kesalahan yang disingkapkan adalah mengenai kelakuan buruk atau doktrin palsu. Seperti halnya mengajar, menyatakan kesalahan berhubungan dengan isi konten Alkitab, dengan memperlengkapi orang-orang percaya dengan pengetahuan dan pemahaman yang benar tentang kebenaran ilahi, dalam konteks ini kebenaran ilahi mengungkap kepalsuan dan dosa, kepercayaan yang salah, dan perilaku yang tidak saleh. Penulis Ibrani berbicara tentang Alkitab sebagai "firman Allah hidup dan kuat dan lebih tajam dari pada pedang bermata dua manapun; ia menusuk amat dalam sampai memisahkan jiwa dan roh, sendi-sendi dan sumsum; ia sanggup membedakan pertimbangan dan pikiran hati kita (Ibr. 4:12)." Jadi Alkitab dengan tepat dan menyeluruh menembus pikiran, jiwa, dan hati orang percaya.

Alkitab adalah standar ilahi yang seharusnya setiap pemikiran, prinsip, tindakan, dan kepercayaan harus diukur. Paulus mengingatkan gereja Korintus tentang apa yang ia ajarkan kepada mereka berkali-kali. "Sebab kami tidak sama dengan banyak orang lain yang

${ }^{23}$ Ola Tulluan, Introduksi Perjanjian Baru ( Batu: YPPII, 2010), 232.

${ }^{24}$ John Drane, Memahami Perjanjian Baru (Jakarta: BPK gunung Mulia, 2011), 394.

${ }^{25}$ John MacArthur, II Timothy (Chicago, Ill. : Moody Press, 1996, c1995), 153.

${ }^{26}$ Philip Towner, 1-2 Timothy \& Titus, The IVP New Testament Commentary Series 14 (Downers Grove, Ill. : InterVarsity Press, 1994), 2 Ti 3:10. 
mencari keuntungan dari firman Allah. Sebaliknya dalam Kristus kami berbicara sebagaimana mestinya dengan maksud-maksud murni atas perintah Allah dan di hadapanNya (2 Kor 2:17)." Lukas memuji orang-orang Yahudi yang takut akan Allah di Berea karena mereka "lebih bermoral daripada orang-orang di Tesalonika, karena mereka menerima firman itu dengan sangat bersemangat, Orang-orang Yahudi di kota itu lebih baik hatinya dari pada orang-orang Yahudi di Tesalonika, karena mereka menerima firman itu dengan segala kerelaan hati dan setiap hari mereka menyelidiki Kitab Suci untuk mengetahui, apakah semuanya itu benar demikian (KPR. 17:11)." Jadi manfaat Alkitab bagi orang percaya adalah sebuah standar yang mengatur segala totalitas dalam hidup.

\section{Memperbaiki kelakuan (Correction)}

Istilah epanorthōsis yang diterjemahankan "correction" dan dalam terjemahan LAI menggunakan kata "memperbaiki kelakuan" hanya digunakan pada ayat ini dalam Perjanjian Baru dan merujuk pada pemulihan sesuatu ke kondisi aslinya. Dalam literatur Yunani sekuler kata tersebut digunakan untuk meletakkan kembali benda yang jatuh dan membantu seseorang berdiri kembali setelah tersandung. ${ }^{27}$

Yesus pernah berkata dalam Yohanes 15:1-2 "Akulah pokok anggur yang benar dan Bapa-Kulah pengusahanya. Setiap ranting pada-Ku yang tidak berbuah, dipotong-Nya dan setiap ranting yang berbuah, dibersihkan-Nya, supaya ia lebih banyak berbuah." Agar dapat membuat umat-Nya patuh, bermanfaat, dan efektif dalam pelayanan-Nya, Tuhan harus memotong bukan saja hal-hal yang berdosa, tetapi juga hal-hal yang tidak berguna. Dia mungkin mengambil hal-hal yang benar-benar baik dalam diri orang percaya, bahkan halhal yang tampaknya perlu, tetapi Yesus mengetahui segala sesuatu, karena yang dipotong adalah hal-hal yang menghalangi pertumbuhan dan pelayanan rohani orang percaya. ${ }^{28}$

\section{Mendidik orang dalam Kebenaran (Instruction which is in Righteousness)}

Istilah Paidea dalam terjemahan KJV menerjemahkan instruction in righteousness, sedangkan dalam terjemahan NIV mengunakan kata "training in righteousness", dan terjemahan LAI menggunakan kata mendidik orang dalam kebenaran. Istilah paideia

\footnotetext{
${ }^{27}$ John MacArthur, II Timothy, 159.

${ }^{28}$ Ibid, 159.
} 
memiliki makna asli yang berarti membesarkan dan melatih anak, tetapi pelatihan ini digunakan untuk segala jenis pelatihan. Kata tersebut juga diterjemahkan "mengoreksi" (2 Tim. 2:25) dan "disiplin" (Ef. 6: 4; Ibr. 12: 5, 7, 11). Dalam konteks ayat 16-17, jelas merujuk pada pelatihan dalam arti yang lebih luas dan mungkin lebih positif, karena yang negatif ditutupi oleh teguran. Melalui Firman-Nya Tuhan secara terus-menerus melatih kita dalam kebenaran. $^{29}$

Seperti halnya pengajaran, teguran, dan koreksi, orang-orang percaya yang saleh dan terutama para pemimpin di gereja adalah instrumen yang melaluinya Alkitab menyediakan pelatihan bagi umat Allah. Tuhan dapat memakai instrumen yang ada untuk melatih atau mendidik orang percaya agar bertumbuh dalam iman dan pengenalan akan Yesus Kristus. Oleh karena yang dilatih, dididik adalah orang berdosa maka diperlukan Alkitab untuk menyatakan mereka membutuhkan keselamatan, karena status orang berdosa maka dibutuhkan didikan yang mengarahkan seseorang kepada kebenaran.

\section{Kedudukan Alkitab bagi Kurikulum}

Sumber otoritas untuk membangun kurikulum adalah Alkitab. Byme merumuskan bahwa sumber otoritas dalam membangun kurikulum dimulai dari :

1. In the devine will (dalam kehendak ilahi).

2. In eternal truth which is the humanistic position (kebenaran di dalam yang humanistis).

3. In science (dalam ilmu pengetahuan).

4. In society, (di dalam masyarakat). ${ }^{30}$

Di sini Alkitab menjadi sumber utama dalam membangun kurikulum. Otoritas ilahi tidak mempunyai kesalahan dan ditulis Allah melalui para nabi-Nya dalam budaya yang berbeda. Berkaitan dengan hal tersebut, ada sepuluh alasan untuk mempercayai Alkitab, yaitu:

1. Alkitab sungguh jujur

2. Ketahanannya

3. Pernyataannya melalui dirinya sendiri

4. Mujizatnya

\footnotetext{
${ }^{29}$ Ibid, 160.

${ }^{30}$ H. W. Byrne, A Christian Appriwich to Education Educatierial Theory and Application (Grand Rapids: Zondervan Publishing House, 1981) 166.
} 
5. Kesatuannya

6. Keakuratannya dari segi sejarah dan geografis

7. Rekomendasi dari Kristus

8. Keakuratan ramalan

9. Keberlangsungan

10. Kuasanya untuk mengubah hidup manusia. ${ }^{31}$

Berkaitan dengan hal tersebut, Homrighausen mengatakan bahwa:

1. Kebenaran Allah bersifat mutlak, sehingga manusia memercayainya.

2. Alkitab adalah kitab yang mutlak karena hanya kitab ini yang menyampaikan Injil Tuhan Yesus Kristus tentang Juruselamat yang masuk ke dunia untuk menebus segala dosa manusia.

3. Alkitab menyatakan kepada manusia bagaimana hubungan antara manusia dengan Allah. ${ }^{32}$

\section{Prinsip-prinsip dalam kurikulum}

Studi Louis E. LeBar mengenai kurikulum yang berpusat kepada Allah meletakan firman Tuhan sebagai dasar dan pusat kurikulum karena tidak ada buku lain yang dapat dibandingkan dengan firman Tuhan. ${ }^{33}$ Berkaitan dengan hal tersebut, Robert L. Woodruff mengatakan bahwa materi pengajaran kurikulum berbasis atau berpusat pada Allah. Dapat difokuskan dalam integrasi antara matra spiritual, akademik (pengetahuan), dan misi pelayanan. "Spiritual Formation (to be like Jesus), mastering a body of knowledge (to know of high academic) and developing professional skill in ministerial practice (to do proclaim of the Gospel). ${ }^{34}$

Lebih dalam lagi, James D. Smart yang dikutip oleh Harianto GP menguraikan beberapa prinsip, yaitu:

1. Fragmentariness. Secara holistik, Alkitab tetap memiliki batasannya. Studi Alkitab dilakukan secara menyeluruh dalam bingkainya, yang adalah Alkitab

\footnotetext{
${ }^{31}$ Bahan artikel ini diambil dari: RBC Ministries, CD SABDA, Topik 27599.

${ }^{32}$ E. G. Homrighausen dan I. H. Enklaar, Pendidikan Agama Kristen (Jakarta:BPK Gunung Mulia, 2018), 63.

33 Harianto GP, Pendidikan Agama Kristen Dalam Alkitab dan Dunia Pendidikan Masa Kini ( Yogyakarta:ANDI, 2016), 115.

${ }^{34}$ Ibid, 116.
} 
2. Historical framework and background dimana sejarah dan latar belakang Alkitab dibutuhkan untuk mengartikan nilai-nilai Alkitab. Jadi, untuk belajar Alkitab juga harus mempelajari sejarah dan latar belakangnya.

3. The veil of moralism di mana belajar Alkitab berarti belajar moral yang benar. Di sini moral bukan hanya dipahami, melainkan juga menjadi ekspresi seseorang yang mempelejarinya

4. The inporttance of grading (pentingnya nilai), bahwa Alkitab adalah pengetahuan yang baik mengenai Allah dan dunia sehingga hal yang baik diberikan atau diajarkan kepada siapa saja, termasuk kepada anak, remaja, pemuda, hingga orang dewasa. Jadi, sesuatu yang baik pasti dibutuhkan setiap manusia.

5. The variety of literary forms (berbagai bentuk kesusteraan), yaitu perlunya fleksibelitas dalam mengajar kepada anak, remaja, atau orang dewasa. Anak bisa saja diajar dengan menggunakan sejarah, himne, hikmat, perumpamaan, khotbah, drama, Injil, atau bentuk surat.

6. The strangeness of the thought forms (keanehan bentuk pemikiran), artinya meskipun Alkitab diterjemahkan dari berbagai bahasa Ibrani, Aram, dan Yunani, tetapi cara berpikir seseorang dapat ditemukan dalam Alkitab

7. A revelation for now (pewahyuan untuk saat ini), artinya sampai sekarang, Allah dalam Alkitab tetap berkata kepada seseorang mengenai hidup, baik di Surga maupun di dunia. Perkataan Allah dari dulu sampai sekarang dalam Alkitab masih relevan dalam berbagai kehidupan manusia di dunia. ${ }^{35}$

\section{Kesimpulan}

Berdasarkan pemaparan di atas dapat disimpulkan bahwa kedudukan Alkitab di era revolusi industri 4.0 tetap menjadi otoritas tertinggi dan mutlak dalam gereja dalam ranah dewasa, karena Alkitab mampu menuntun orang percaya untuk:

1. Bertumbuh dalam spiritualitas (hubungan dengan Tuhan)

2. Bersosial (kehidupan dengan sesama)

3. Pengetahuan (iman kristen)

${ }^{35}$ Ibid, 116-117. 
4. Mengajarkan untuk melakukan apa yang di ketahui.

\section{Referensi}

Lembaga Alkitab Indonesia (Jakarta: Lembaga Alkitab Indoensia, 1975).

Anthony, Michael J., Fondasi Pendidikan Abad 21, Gandum Mas 2017.

GP, Harianto, Pendidikan Agama Kristen Dalam Alkitab dan Dunia Pendidikan Masa

Kini, Yogyakarta:ANDI, 2016.

Gorday, Peter, Colossians, 1-2 Thessalonians, 1-2 Timothy, Titus, Philemon, Downers Grove, Ill. : InterVarsity Press, 2000.

Homrihausen, E. G. \& Enklaar, I. H., Pendidikan Agama Kristen, Jakarta: BPK Gunung Mulia, 2018.

Imaduddin, Muhammad, Membuat Kelas Online Berbasis Android dengan Google Classroom Terobosan Pembelajaran Era Revolusi Industri 4.0, Yogyakarta: Garudhawaca, 2018.

Lea, Thomas D., Griffin, Hayne P., 1 \& 2 Timothy, The New American Commentary 34 Titus, Nashville: Broadman \& Holman Publishers, 2001, 1992.

McGee, J. Vernon, Thru the Bible Commentary: The Epistles $(1$ and 2 Timothy/Titus/Philemon), Nashville : Thomas Nelson, 1991.

Tulluan, Ola, Introduksi Perjanjian Baru, Batu: YPPII, 2010.

Drane, John, Memahami Perjanjian Baru, Jakarta: BPK gunung Mulia, 2011.

MacArthur, John, II Timothy, Chicago, Ill. : Moody Press, 1996, c1995.

Towner, Philip, 1-2 Timothy \& Titus, The IVP New Testament Commentary Series 14, Downers Grove, Ill. : InterVarsity Press, 1994. 